\title{
Determinant of Selection of Offline Marketing Model of Agricultural Products in Banjar Agropolitan City
}

\author{
Sri Mulyati ${ }^{1}$, Hasan Fahmi Kusnandar ${ }^{2}$, Maman Sulaeman ${ }^{3}$ \\ ${ }^{1,2,3}$ Polytechnic of Triguna, Tasikmalaya, Indonesia \\ mansulaeman1274@gmail.com
}

\begin{abstract}
The agricultural sector still plays an important role at both the national and regional levels, but that role tends to decrease in line with the increase in per capita income reflecting a process of structural transformation. This decrease is due to the interaction of various processes that work on the demand side, supply and activity shifts. This research aims to analyze the determinant of the selection of offline marketing models of agricultural products in the agropolitan city of Banjar West Java. This research is categorized as explanatory research which is a study that aims to explain the causal relationship between variables through hypothesis testing. The Inference Statitic method used in the analysis of this research data is the path of analysis. Based on the results of research shows that the most influential factor on offline marketing selection is affordability that there are still consumers who have not yet reached information technology, then is trust, booster promotion, doubt and Competition.
\end{abstract}

Keywords

affordability of

information

technology; trust, booster promotion; doubt and competition

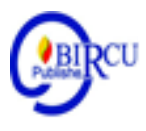

\section{Introduction}

The development of strategic areas is very closely related to efforts to solve the inherent and growing problems within it. A series of measures arranged in order to solve the problem will work well if supported by a mature development planning process. One of the prerequisites that the development process will achieve its goals is to know if the main issues and problems in a city can be recognized and formulated properly. There must be a good strategic development strategy for the comfort of a large city such as Banjar city to this agropolitan city. Development strategies need to have a strategic framework both at the local or regional level and at the national level. In this framework local governments can design their local urban development strategies, which accommodate local conditions and necessary variations. The framework of the regional development strategy needs to be balanced and balanced in order for development to be targeted. This development strategy is carried out by elaboration of spatial structuring policy into more tangible measures of achievement that are the basis in the preparation of the structure plan and the pattern of space of the city area.

In this economic development, the agricultural sector is still expected to make a meaningful contribution in the increase in national income, especially in the provision of jobs and the provision of food. The agricultural sector still plays an important role at both the national and regional levels, but that role tends to decrease in line with the increase in per capita income reflecting a process of structural transformation. This decrease is due to the interaction of various processes that work on the demand side, supply and activity shifts. The agricultural sector will not develop and benefit the People of Indonesia if it is not supported by primary agriculture as a producer of raw materials. Primary agriculture will not be able to 
thrive if it is not supported by the development of industries that produce production facilities.

Currently Indonesia has entered conditions that force farmers as the main producers of agricultural products directly and indirectly enter competition with many other producers at the global level. Agricultural products compete not only with overseas agricultural products in the global market but also in the domestic market. In such conditions the competition becomes more intense, strong manufacturers compete with weak manufacturers, as a result the less competitive producers will become increasingly alienated. Such a situation is now taking place with agricultural products, especially fruit and vegetable food products (Setiawan, 2018).

These developments have led to competition among companies. The number and type of products produced, causing increasing competition among similar product producing companies. Therefore, the company is also encouraged to be able to improve the quality and quantity of its product results as well as to do the concept of marketing quickly and precisely. Marketing is a process that aims to meet the needs and desires of consumers who are closely related to the company's ability to make a profit. The Company needs to formulate a marketing strategy that fits the situation and conditions. The transfer of agricultural land is a threat to the achievement of food security and sovereignty that has serious implications for food production, physical environment, and welfare of agricultural and rural communities whose lives depend on the land. Policies related to the implementation of the Law. No. 41 Year 2009 in addition to being directed to prevent the transfer of fertile land to non-agricultural land, also directed at the development program through integrated efforts to print potential new agricultural land.

Agropolitan Area Development is the right alternative solution in rural development without forgetting urban development. Through the development of agropolitan areas, there is expected to be a strong interaction between the center of the region and the agricultural production area. Through the agropolitan system approach, agricultural products will be processed first in the center of the region before being sold to the market (export), so that the added value remains in the Agropolitan Area (Daidullah, 2016:1). Agricultural development is very strategic, hence the revitalization of agriculture needs to be realized immediately. Various support sectors need to be smoothed out, all potential superior products must be worked on, by deploying existing workforce, to prevent the urbanization of labor from Village to City. Such an atmosphere is very likely to be realized when rural areas are developed into "agropolitan" areas. Agropolitan comes from two words, namely Agro = agriculture and Politan = city, so the understanding of Agropolitan is an agricultural city that grows and develops, able to serve, encourage, attract, heed agricultural development activities (agribusiness) in the surrounding area (Daidullah. 2006:1).

Banjar city as one of agropolitan city that produces fruits and vegetables commodities face obstacles in marketing such as: the properties of fruits and vegetables commodities that are easily damaged, become a problem for farmers and traders because it can pose physical risks and prices for agribusiness actors. The low quality of fruit and vegetable products is closely related to production systems, harvest systems, post-harvest ingestion, distribution and marketing systems. Agricultural products in Banjar city are generally still widely marketed in primary form (not yet processed). The type of product is still not handled to the maximum and the quality is still diverse so the competitiveness in the market is relatively low.

The results of Cahyono research (2018) show offline marketing proved to have an effect on consumer satisfaction, while consumer satisfaction also proved to have an effect on consumer loyalty. Therefore, strengthening the offline marketing strategy will have an 
impact and influence on satisfaction and therefore will further strengthen the loyalty of consumers. The company uses offline due to the type of product that is not durable.

Møller's research, and Stubbe (2014) also supported research conducted by Zhang (2015), who said that for some products consumers prefer to shop offline. Products that consumers choose in offline purchases are usually such as motorcycles, cars and cosmetics. It is the consumer who wants to see it and try the product directly. Research on offline purchases by Lalwani (2016), stated that many consumers still choose to make purchases offline, because they can feel the goods directly and can come face to face with the seller. Another study conducted by Gallino and Moreno (2012), stated that there are still many consumers who choose to make purchases offline rather than online. Purchases made offline have an impact on the increase in existing purchases at the store. Consumers will find it easier to get goods when consumers can choose goods directly and can interact with store owners.

\section{Review of Literatures}

Offline Marketing or commonly referred to as Direct Sales according to wikipedia has the understanding of a strategy to market its products or services aimed at influencing consumer actions. Direct selling emphasizes decision-making based on rationality or because of the additional profit a product is given. Offline marketing also has another term namely direct selling which translates as a direct selling method where the marketer or manufacturer approaches potential customers directly with the goods or services offered for example is property offers by phone, kalatog/brochure, outdoor advertising (web marketing, December 2016). An example of the above strategy is, PT. Adinata Graha Raya creates a market database based on age, profession, income, and social background. They offer units that are in PT. Adinata Graha Raya based on price and based on the data base created so as to obtain the right segmentation. According to web marketing (December 2016) the form of direct sales can be found in the form of sales promotion, personal selling, direct response marketing, as well as merchandising and point of purchase. The purpose of direct marketing is to inform the customer about any products or services that may be needed without waiting for the customer to seek information about the product or service.

Nowadays, there are entrepreneurs (through marketing) who promote their flagship goods/services through online media such as social media, web, blogs, and others. This is noted because many of them think that promotion through online media has a lower budget than through offline or print media. In addition, the reach of online media is wider than offline media. Online marketing or also commonly referred to as digital marketing offers a wide range of conveniences for marketers to expand the range of product promotion. The above assumptions are not entirely false, but they are not entirely true. Although in the modern era it is all digital, but not necessarily products or forms of offline marketing activity disappear and ineffective. Even in some aspects, offline marketing promises more feedback than digital marketing. According to Mahardika (2018) the reason why offline promotion is still considered important.

1. Many people are still hesitant with online

Not all potential customers, especially generations $\mathrm{X}$ and $\mathrm{Y}$, are convinced of what is shown in cyberspace. They need a real form of media/results from our products/ services, so that they are more confident with our products/services. 
2. Increase trust from customers at a certain level

When online promotional media can't be seen physically, in this real/offline world there's a lot to see in person. Prospective customers are more likely to trust this offline form because there is a physicality that can be seen directly. For example, brochures, posters, banners, or even billboards.

3. As an online promotion booster

Instagram has been built, Facebook has been managed, Twitter is maxed out, but customers are still quiet? There's no need to hand out brochures around or in the crowd. Who knows if potential customers are in the community/market segment who prefer the form of marketing with offline media.

4. High potential to win competition

If the online and offline markets are already controlled and both strengthen each other, just multiply the portfolio or testimonials from previous customers. But the most important thing is to maintain the quality of the products and services offered.

5. Reach generations untouched by technology

Although there is now an era of social media and technology, not all potential customers are there. Not closing the possibility, potential customers of the untouchable generation of social media, or even from those who consider social media insane, just to play around.

\section{Research Method}

This research is categorized as explanatory research, which aims to explain the causal relationship between variables through hypotheses test. This research approach is a survey approach. The populations in this study were all kelompok tani di Kota Banjar. The data taken about 300 people. The inferential statistical method used in the data analysis of this research is path analisys. Reasons for using path analisys, consideration that the causal relationship formulated in this study uses a non-simple model that has multiple roles such as variables. This form of causal relationship requires analysis that is able to explain simultaneously about the relationship so that the method used in this study uses path analisys.

\section{Discussion}

Data processing results can be partially known the effect of Doubt, Trust, Promotion Booster, Competition and Affordability on offline marketing selection can be found in Table 1 below:

Table 1. The Effect of Doubt, Trust, Promotion Booster

\begin{tabular}{|c|c|c|c|c|c|c|}
\hline \multirow{2}{*}{\multicolumn{2}{|c|}{ Model }} & \multicolumn{2}{|c|}{$\begin{array}{l}\text { Unstandardized } \\
\text { Coefficients }\end{array}$} & \multirow{2}{*}{$\begin{array}{c}\text { Standardized } \\
\text { Coefficients } \\
\text { Beta }\end{array}$} & \multirow[b]{2}{*}{$\mathrm{T}$} & \multirow[b]{2}{*}{ Sig. } \\
\hline & & B & Std. Error & & & \\
\hline \multirow[t]{6}{*}{1} & (Constant) & .312 & 1.197 & & .260 & .795 \\
\hline & Keraguan & .370 & .127 & .166 & 2.902 & .004 \\
\hline & Kepercayaan & .594 & .146 & .282 & 4.065 & .000 \\
\hline & Penguat Promosi & .299 & .078 & .107 & 3.838 & .000 \\
\hline & Persaingan & .297 & .159 & .143 & 1.869 & .044 \\
\hline & Keterjangkauan & .443 & .104 & .352 & 4.243 & .000 \\
\hline
\end{tabular}

Dependent Variabel:Pemasaran Ofline 
Based on the table above can be made analysis of the determinant path of selection of offline marketing model of agricultural products in Agropolitan Banjar City as follows:

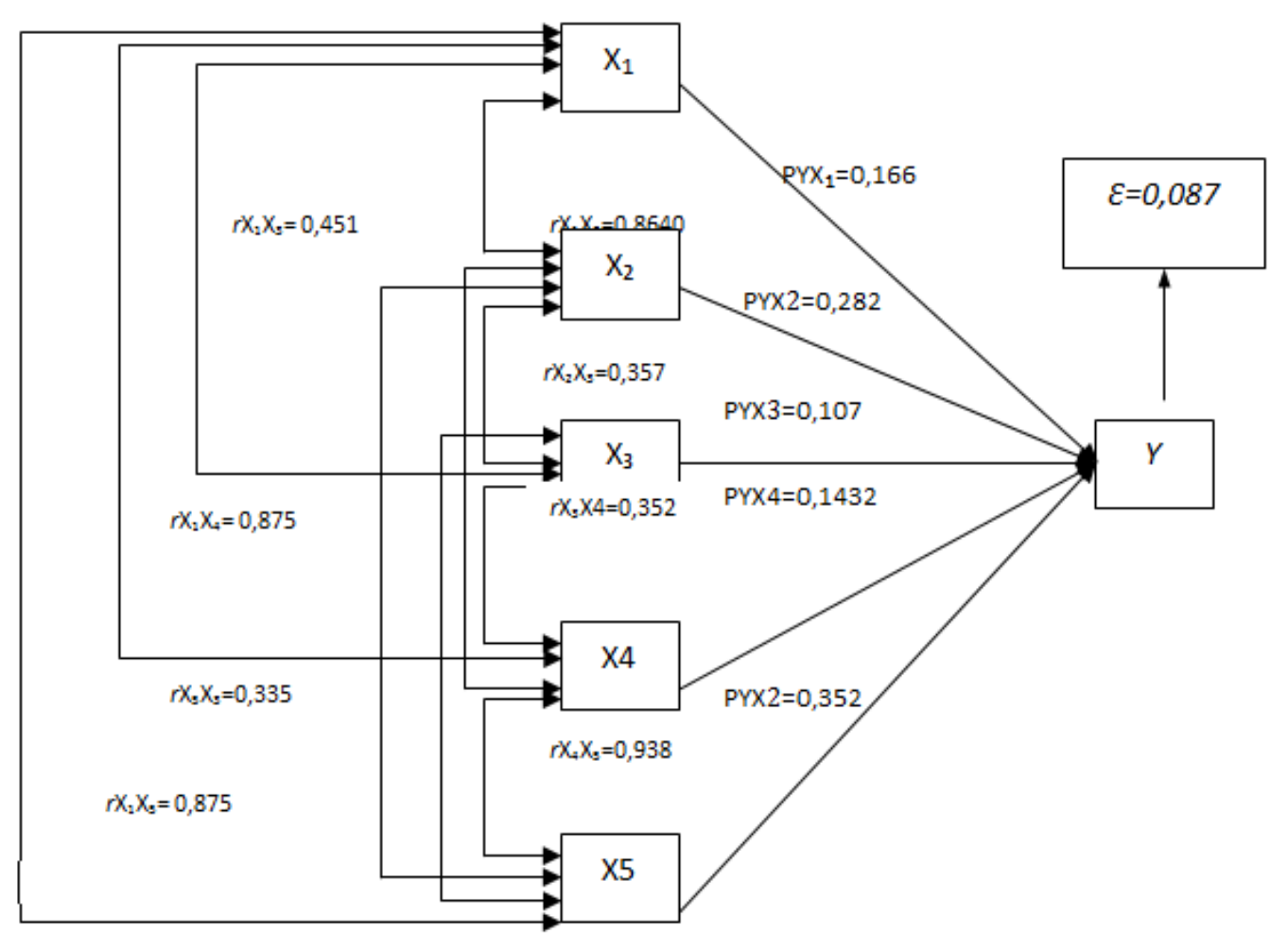

Figure 1. Analysis of the Determinant Path

Based on the results of the study obtained data that the factor that has the most influence on offline marketing selection is affordability. The offline marketing strategy is, there is a transaction that directly manufacturers and consumers can meet. Offline marketing is still effectively used by business people in promoting their products/services because offline marketing still has a significant impact on business sales if applied optimally. Offline marketing is still necessary even though online marketing is popular and has a big influence on the community. Online marketing cannot reach all walks of life. Even in Indonesia today, many are still blind or do not know the internet.

Offline marketing from $\mathrm{TV}$, radio to newspapers is still effective as a means of advertising. For example, for parents who do not understand about the internet, they will get all the information through the TV, radio, or newspaper. Moreover, for Indonesians who live in the corners of the country and have not been completely touched by the internet or TV. Then the only marketing strategy used is offline marketing. So, although online marketing has a big impact on promotional media, it does not make offline marketing useless. If in an online business can not be seen physical business and its implementation, in the real world or in this offline business there are many things that can be seen directly and buyers or customers are more likely to trust this offline business, because there is a physical ity that can be seen directly. Offline marketing strategy is still used by business people today. By implementing offline marketing can reach Indonesians who do not have internet access. So that the products or services that businesspeople want to deliver to prospective customers can be accepted by the public. 
The results of this study are in line with Widawati's research (2018) that the reach of the area of online internet and social media systems is wider than that of offline systems, but there are still unreachable. Online marketing strategies complement each other with offlne marketing strategies. Basically online marketing and offline marketing have their own advantages and disadvantages. Offline marketing is still considered important because many people are still hesitant with online marketing, increasing the trust of customers at some level, as an online promotion booster, high potential to win competition, and the reach of generations untouched by technology

\section{Conclusion}

Based on the results of research shows that the most influential factor on offline marketing selection is affordability that there are still consumers who have not yet reached information technology, then is trust, booster promotion, doubt and Competition. Although there is now an era of social media and technology, not all potential customers are there. Not closing the possibility, potential customers of the untouchable generation of social media, or even from those who consider social media insane, just to play around. Not all potential customers, especially generations $\mathrm{x}$ and $\mathrm{y}$, are convinced of what is shown in cyberspace. They need a real form of media/results from our products/ services, so that they are more confident with our products/services.

\section{Acknowledgement}

This research was supported by the Ministry of Research, Technology and Higher Education through the Directorate of Research and Community Services (DRPM), Beginner Lecturer Research Scheme 2020. Therefore, we would like to express our sincere gratitude. Any opinions, findings, and conclusions or recommendations expressed in this article are those of the authors and do not necessarily reflect the views of the respected ministry.

\section{References}

Abdurrahman, B. (2005). Regional Management and Regional Marketing. Penerbit Ikatan Ahli Perencanaan Indonesia. Semarang.

Alkadri Muchdie dan Suhandojo. (2001). Tiga Pilar Pengembangan Wilayah: Sumberdaya Alam, Sumberdaya Manusia dan Teknologi. Jakarta: Pusat Pengkajian Kebijakan Teknologi Pengembangan Wilayah. BPPT.

Almahdi, Syahza. (2017). Model Pemasaran Produk Pertanian Berbasis Agribisnis Sebagai Upaya Percepatan Pertumbuhan Ekonomi Pedesaan, dalam Jurnal Ekonomi, Th.XIII/01/Maret/2008, PPD\&I Fakultas Ekonomi Universitas Tarumanagara, Jakarta

Anwar A., 2005. Ketimpangan Pembangunan Wilayah dan Perdesaan : Tinjauan Kritis. Bogor:P4Wpress.

Assauri, Sofjan. (2013). Manajemen Pemasaran. Jakarta : Rajawali Pers

Budiharsono, S 2002 Pengembangan Ekonomi Lokal Dan Daerah Untuk. Meningkatkan Daya Saing Daerah. Bogor.

Burak Ozdogan, Anıl Gacar, Huseyin Aktas, (2017). Digital Agriculture Practices In The Context Of Agriculture 4.0, Journal of Economics, Finance and Accounting - (JEFA), ISSN: 2148-6697, http://www.pressacademia.org/journals/jefa. 
Daidullah, Samsudin T. 2016. Strategi Pengembangan Agropolitan Dinas Tanaman Pangan Hortikula, Perkebunan dan Peternakan Kabupaten Boul. Yogyakarta.

Effendy Anwar. (2016). Ketimpangan Pembangunan Wilayah dan Pedesaan, Tinjauan Kritis. Bogor: P4Wpress.

Elvinaro, Ardianto. (2011). Komunikasi pembangunan dan perubahan sosial. Jakarta: PT Raja Grafindo Persada.

Fiske, FB. (2012) Arah Pembangunan Desentralisasi Pengajaran Politik dan Konsensus , Jakarta, Gramedia.

Friedman, John, dan William Alonso. (2008). Regional Development and Planning: A Reader, The M.I.T Press, Massachussetts.

Hasibuan, A.S., Fitrawaty, and Rahmadana, M.F. (2020). The Analysis of the Effect of Determinant Factors of Palm Oil Plantation Sector on Agricultural Sector Growth in North Sumatera. Budapest International Research and Critics Institute-Journal (BIRCIJournal) Vol 3 (2): 1083-1094.

Iwan Setiawan, dkk, .(2018). Pertanian Postmodern Penerbit : Penebar Swadaya, Jakarta

Kaplan Michael HaenLein, (2010). User Of The World, Unite! The Challenges and Opportunities Of Social Media, Business Horizons.

Kennedy, John. E; R Dermawan Soemanagara. .(2016). Marketing Communication - Taktik dan Strategi. Jakarta. PT Buana Ilmu Populer (kelompok Gramedia).

Kotler, P \& K. L. Keller. (2012). Marketing Management 12th. Gramedia. Jakarta. 812 p.

Liliweri, Alo. (2011). Komunikasi Serba Ada Serba Makna.Jakarta : Prenada Media Group.

Lubis, N.P., Nugrahadi, E.W., and Yusuf, M. (2020). Analysis of Superior Commodities in Agricultural Sector in Some Districts of North Sumatera Province. Budapest International Research and Critics Institute-Journal (BIRCI-Journal) Vol 3 (2): 10541066.

Mercado, R.G. (2002). Regional Development in The Philippine: A Review of Experience, State of The Art and Agenda for Research and Action, Manila: Phillipine Institute for Development Studies.

Mondry .(2015). Pemahaman Teori dan Praktik Jurnalistik. Bogor: Ghalia Indonesia

Mulyana Deddy. (2014). Ilmu Komunikasi Suatu Pengantar. Bandung: PT Remaja Rosdakarya.

Nimmo Dan. (2015). Komunikasi Politik Komunikator, Pesan, dan Media. Bandung:PT Rempaja Rosdakarya.

Rustiadi, Ermam dkk. (2018). Perencanaan dan Pengembangan Wilayah". Jakarta: Yayasan Pustaka Obor Rakyat.

Shrikant Waghulkar Balaji skk. (2017). A Feasibility Study For Online Marketing Of Agricultural Greenhouse Products W.R.T. Pune District International Journal of Management (IJM) Volume 8, Issue 1, January-February 2017, pp.98-110, Article ID: IJM_08_01_011.Available online at .

$\mathrm{http} / / \mathrm{www}$. iaeme.com/ijm/issues.asp?JType=IJM\&VType=8\&IType=1 Journal Impact Factor (2016): 8.1920 (Calculated by GISI) www.jifactor.com ISSN Print: 0976-6502 and ISSN Online: 0976-6510.

Silalahi, H.P. (2019). Social Capital as a Local Wisdom of Farmer in Managing Agricultural Resources in Lubuk Pakam Sub-district, Deli Serdang District Sihar. Budapest International Research and Critics Institute-Journal (BIRCI-Journal) Vol 2 (4): 469476. 
Sulaeman, Maman, Establish a Competitive Advantage with Market Sensing Capability, Distinctive Competence and Product Innovation for Performance Marketing and Sustainability Efforts, Journal of Physics: Conference Series, Volume 1477, Science https://iopscience.iop.org/article/10.1088/1742-6596/1477/7/072019/meta.

White, Danielle. Courtney Meyers. (2014). Exploring Agriculturalists' Use of Social Media for Agricultural Marketing. Journal of Applied Communication. 